\title{
Combination of five clinical data as prognostic factors of mortality after ischemic stroke
}

\author{
Rizaldy Taslim Pinzon*, Fransiska Theresia Meivy Babang*, \\ and Esdras Ardi Pramudita*
}

\begin{tabular}{l}
\hline \\
\hline \\
*Faculty of Medicine, \\
Duta Wacana Christian University/ \\
Bethesda Hospital, Yogyakarta \\
Correspondence: \\
dr. Rizaldy Taslim Pinzon, SpS, M.Kes \\
Faculty of Medicine, \\
Duta Wacana Christian University \\
J1. Dr. Wahidin Sudiro Husodo \\
No.. 5-25 Yogyakarta 55224 \\
Email: drpinzon17@ gmail.com
\end{tabular}

Univ Med 2017:36:68-76

DOI: 10.18051/UnivMed.2017.v36.68-76 pISSN: 1907-3062 / eISSN: 2407-2230

Received August 8, 2016

Accepted for publication April 25, 2017

This open access article is distributed under a Creative Commons Attribution-Non Commercial-Share Alike 4.0 International License

\section{BACKGROUND}

The mortality rate after ischemic stoke is influenced by various factors. Prognosis after ischemic stroke can be predicted using a scoring system to help the doctor to evaluate patient's condition, neurologic deficits, and possible prognosis as well as make appropriate management decisions. The objective of this study was to identify the factors which determine mortality rates in patients after ischemic stroke and to determine the prognosis of ischemic stroke patients using the predictive mortality score.

\section{METHODS}

This was a nested case control study using data from the stroke registry and medical records of patients at the Neurology Clinic of Bethesda Hospital Yogyakarta between 2011-2015. Data was analysed using simple and multiple logistic regression analysis. The scoring was analyzed using receiver-operating characteristic (ROC) curve and the cut-off point using area under the curve (AUC).

\section{RESULTS}

Multiple logistic regression analysis showed a significant association between mortality of ischemic stroke patients and age (OR: 4.539, 95\% CI: 1.974-10.439, p<0.001), random blood glucose (OR: 2.692, 95\% CI: 1.580-4.588, $\mathrm{p}<0.001$ ), non-dyslipidemia (OR: 2.313, 95\% CI: 1.3953.833, $\mathrm{p}=0.001$ ), complications (OR: 1.609, 95\% CI: 1.019-2.540, $\mathrm{p}=0.041$ ), risk of metabolic encephalopathy (OR: $2.499,95 \%$ CI: $1.244-$ $5.021, \mathrm{p}=0.010)$ and use of ventilators (OR: 17.278, 95\% CI: 2.015148.195, $\mathrm{p}=0.009)$.

\section{CONCLUSIONS}

Age, high random blood glucose level, complications, metabolic encephalopathy risk and the use of ventilators are associated with mortality after ischemic stroke. The predictive mortality score can be used to assess the prognosis of patients with ischemic stroke.

Keywords: Ischemic stroke, causes of mortality, predictive mortality score 


\section{INTRODUCTION}

Ischemic stroke is an episode of neurologic dysfunction that is caused by focal infarction of the brain, spinal cord and retina. ${ }^{(1)}$ Each year the number of stroke patients is increasing. The prevalence of stroke (with the criterion of having been diagnosed by health personnel) of 8.3 per 1000 in the Indonesian Basic Health Research survey for 2007 (Riskesdas 2007) increased to 12.1 per 1000 in 2013 (for stroke respondents aged 15 years and above). (2) From data at the stroke registry of Bethesda Hospital for 2014 it is known that each trimester the number of patients with stroke is increasing. Of 2460 stroke patients at Bethesda Hospital between 2011 and 2013, a total of $9.47 \%$ had died. ${ }^{(3)}$

There are many factors that influence the cause of death in patients with ischemic stroke. Age, stroke subtype, atrial fibrillation, history of previous strokes/transient ischemic attack, albumin, creatinine, von Willebrand factor and B-thromboglobulin are the factors that can predict death in patients with ischemic stroke. ${ }^{(4)}$ The study of Mogensen et al. ${ }^{(5)}$ on cause-specific mortality after stroke found that hypertension, smoking and alcohol consumption were not associated with cause-specific death. Previous studies reported that antihypertensive treatment directly after acute ischemic stroke may increase the mortality rate. ${ }^{(6)}$ Other studies state that hypertension is the factor that is most frequently found in stroke patients. The factors that influence the prognosis of stroke patients are age, mean corpuscular volume (MCV), folic acid, and erythrocyte sedimentation rate (ESR). Advanced age, high MCV and low folic acid concentration in stroke patients are associated with a poor prognosis. ${ }^{(7)}$ Çomoðlu et al. ${ }^{(8)}$ in their study state that ESR level of patients at admission do not reflect stroke severity and cannot be used as a useful predictor for evaluating the short term prognosis of patients with acute ischemic stroke. The predictive factors of mortality in stroke patients are still varied and subject to debate.
The prognosis of ischemic stroke can be predicted by scoring. The use of a scoring system can help doctors in evaluating the initial condition of the patients, giving a rapid and accurate evaluation about deficits in stroke, thus facilitating communication between doctors and saving time for triage and treatment of the patients. ${ }^{(9)}$ The objective of this study was to identify the factors that influence mortality in patients with ischemic stroke and determine the prognosis of these patients using the predictive mortality score.

\section{METHODS}

\section{Design of study}

This independent nested case control study was conducted at Bethesda Hospital, Yogyakarta, from February until March 2016 using secondary data from the stroke registry and medical records at Bethesda Hospital, Yogyakarta, from 2011 up to and including 2015.

\section{Study subjects}

The study subjects were patients with ischemic stroke over 40 years of age who had been diagnosed by head CT scan from 2011 to 2015 at Bethesda Hospital, Yogyakarta, whose data in the stroke registry and the medical records were complete, and had not been discharged against medical advice. Sample size was calculated according to the formula for differences in proportions of two populations. Based on the formula for sample size calculation, the sample comprised 179 deceased patients and 179 live patients so that the total sample size required was 358 patients.

\section{Measurements}

The age of the patients was calculated from the number of years from birth up to the last data collection at the hospital. The level of consciousness was assessed with the Glasgow Coma Scale (GCS) or noted in the medical record as compos mentis or somnolence or stupor or 
coma. Muscle strength was assessed on the Medical Research Council (MRC) scale. Systolic blood pressure, diastolic blood pressure, random blood glucose and leukocyte count were obtained from the results of examination at admission. Patients were declared to be at risk for metabolic encephalopathy due to intoxication, renal disorders (uremic encephalopathy), pulmonary or hepatic disorders (hepatic encephalopathy) from the changes in electrolyte or enzyme concentrations or ureum/creatinine concentrations (sodium concentration $<125$ $\mathrm{mmol} / \mathrm{L}$ or SGOT or SGPT or ureum or creatinine concentration $>3$ times the normal concentrations). Patients were declared have a history of hypertensive disease if they had ever been diagnosed with hypertension or consumed antihypertensive medications, or had blood pressures of $>140 / 90 \mathrm{mmHg}$ at 2 readings. Patients were declared to have atrial fibrillation by a cardiologist on the basis of their EKG. Patients were declared to have a history of dyslipidemia if they had ever been diagnosed with dyslipidemia or consumed statins/fibrate, or their cholesterol concentration was $>200 \mathrm{mg} / \mathrm{dL}$ or triglycerides $>150 \mathrm{mg} / \mathrm{dL}$ (fasting) or HDL $<40$ $\mathrm{mg} / \mathrm{dL}$ or $\mathrm{LDL}>100 \mathrm{mg} / \mathrm{dL}$. Patients were declared to have a history of diabetes mellitus if they had ever been diagnosed with diabetes mellitus or consumed antidiabetics, or from the results of laboratory examination of random blood glucose of $\geq 200 \mathrm{~g} / \mathrm{dL}$ or fasting blood glucose of $\geq 126 \mathrm{~g} / \mathrm{dL}$. The complications that were investigated in this study were the other disorders that emerged during hospitalization of the stroke patients and were noted in the medical records, i.e. gastrointestinal bleeding, dysphagia and urinary tract infections.

\section{Data analysis}

Data were analyzed by descriptive analysis and statistical analysis. Descriptive analysis comprised characteristic data of all patients, whereas statistical analysis comprised univariate, bivariate and multivariate analysis and validation tests using receiver-operating characteristic (ROC) curves, whereas for cutoff point the area under the curve (AUC) was used. The discrimination model was determined from the area under the ROC curve that was calculated by nonparametric methods. The area under the ROC curve is a measure of total predictive discrimination to separate patients with good outcomes from patients with poor outcomes. A ROC curve area of 0.5 indicates no discrimination, and an area of 1.0 indicates perfect discrimination. Determination of the cutoff point in this study was evaluated by logistic regression to obtain the largest area under the curve. ${ }^{(10)}$

\section{Ethical clearance}

This study was observational on secondary data from the registry. For this study ethical clearance was obtained from the Research Ethics Committee, Faculty of Medicine, Duta Wacana Christian University, under no. 152/ C/16/ FK/ 2016.

\section{RESULTS}

Table 1 above shows the baseline characteristics of all study samples that were analyzed descriptively. A total of 358 patients meeting the inclusion and exclusion criteria were recruited into this study, consisting of 203 male patients (56.7\%) and 155 female patients (43.3\%). The most numorous subjects were in the age range of $>70$ years, comprising 121 patients $(33.8 \%)$. The most frequent onset to admission time was $>24$ hours $(44.1 \%)$.

The relationship of predictive factors of mortality with the dependent variables listed in Table 2 above shows that the variables that have a significant relationship with mortality in ischemic stroke patients $(\mathrm{p}<0.05)$ are age, level of consciousness, muscle strength, side of weakness, systolic blood pressure, diastolic blood pressure, leukocyte count, random blood glucose, history of dyslipidemia, complications, risk of metabolic encephalopathy and use of ventilators. 
Table 1. Baseline characteristics of all patients

\begin{tabular}{|c|c|c|c|c|}
\hline Chara cte ristic & $\mathrm{n}=358$ & $\%$ & Died & $\%$ \\
\hline \multicolumn{5}{|l|}{ Gender } \\
\hline Male & 203 & 56.7 & 104 & 29.1 \\
\hline Female & 155 & 43.3 & 75 & 20.9 \\
\hline \multicolumn{5}{|l|}{ Age } \\
\hline $40-50$ years & 40 & 11.2 & 10 & 2.79 \\
\hline $51-60$ years & 81 & 22.6 & 38 & 10.61 \\
\hline $61-70$ years & 116 & 32.4 & 57 & 15.92 \\
\hline$>70$ years & 121 & 33.8 & 74 & 20.67 \\
\hline \multicolumn{5}{|l|}{ Level of consciousness } \\
\hline Compos mentis & 198 & 55.3 & 78 & 21.79 \\
\hline Somnolence & 107 & 29.9 & 63 & 17.59 \\
\hline Stupor & 50 & 14.0 & 35 & 9.78 \\
\hline Coma & 3 & 0.84 & 3 & 0.84 \\
\hline \multicolumn{5}{|l|}{ Onset to admisciontime } \\
\hline$<3$ hours & 36 & 10.1 & 17 & 4.75 \\
\hline 3-6 hours & 72 & 20.1 & 35 & 9.78 \\
\hline $6-12$ hours & 51 & 14.2 & 25 & 6.98 \\
\hline $12-24$ houss & 41 & 11.5 & 18 & 5.03 \\
\hline$>24$ hours & 158 & 44.1 & 84 & 23.46 \\
\hline \multicolumn{5}{|l|}{ Smoking } \\
\hline Yes & 14 & 3.91 & 4 & 1.12 \\
\hline No & 344 & 96.1 & 175 & 48.88 \\
\hline \multicolumn{5}{|l|}{ Muscle strength } \\
\hline Active movem ent ag sinst full resistance & 66 & 18.4 & 25 & 6.98 \\
\hline Active movem ent ag ainst gravity and some resistance & 53 & 14.8 & 18 & 5.03 \\
\hline Active movem ent ag inst gravity & 40 & 11.2 & 18 & 5.03 \\
\hline Active movem ent with elim ination of gr avity & 29 & 8.1 & 17 & 4.75 \\
\hline $\mathrm{Few}$ visible contractions & 99 & 27.7 & 55 & 15.36 \\
\hline No visible contractions & 10 & 2.8 & 3 & 0.84 \\
\hline Undetermined & 61 & 17 & 43 & 12.01 \\
\hline \multicolumn{5}{|l|}{ Side of weakness } \\
\hline N either & 77 & 21.5 & 33 & 9.22 \\
\hline Right & 119 & 33.2 & 59 & 16.48 \\
\hline Left & 119 & 33.2 & 57 & 15.92 \\
\hline Right and left & 15 & 4.2 & 8 & 2.23 \\
\hline Undetermined & 28 & 7.8 & 22 & 6.15 \\
\hline \multicolumn{5}{|l|}{ Systolic BP (m m Hg) } \\
\hline$\leq 129$ & 64 & 17.9 & 41 & 11.45 \\
\hline $130-139$ & 48 & 13.4 & 21 & 5.87 \\
\hline$\geq 140$ & 246 & 68.7 & 117 & 32.68 \\
\hline \multicolumn{5}{|l|}{ Diastolic BP (mm Hg) } \\
\hline$\leq 84$ & 127 & 35.5 & 76 & 21.23 \\
\hline $85-89$ & 0 & 0 & 0 & 0 \\
\hline$\geq 90$ & 231 & 64.5 & 103 & 28.77 \\
\hline \multicolumn{5}{|l|}{ Leuk ocyte count $\left(\times 10^{3} / \mathrm{mm}^{3}\right)$} \\
\hline$\leq 11$ & 202 & 56.4 & 91 & 25.42 \\
\hline$>11$ & 156 & 43.6 & 88 & 24.58 \\
\hline \multicolumn{5}{|l|}{ Random tood gucose $(\mathrm{g} / \mathrm{dL})$} \\
\hline$<200$ & 266 & 74.3 & 120 & 33.52 \\
\hline$\geq 200$ & 92 & 25.7 & 59 & 16.48 \\
\hline \multicolumn{5}{|l|}{ Atrial fibrill ation } \\
\hline Yes & 16 & 4.5 & 8 & 2.23 \\
\hline No & 342 & 95.5 & 171 & 47.77 \\
\hline \multicolumn{5}{|l|}{ History of diabetes m ellitus } \\
\hline Yes & 18 & 5 & 13 & 3.63 \\
\hline No & 340 & 95 & 166 & 46.37 \\
\hline
\end{tabular}


Table 1. Cont.

\begin{tabular}{|c|c|c|c|c|}
\hline Chara cte ristic & $\mathrm{IF}=\mathbf{3 5 8}$ & $\%$ & Died & $\%$ \\
\hline \multicolumn{5}{|l|}{ History of hypertension } \\
\hline $\mathrm{Yes}$ & 189 & 52.8 & 90 & 25.14 \\
\hline No & 169 & 47.2 & 89 & 24.86 \\
\hline \multicolumn{5}{|l|}{ History of dyslipidemia } \\
\hline$Y$ es & 107 & 29.9 & 39 & 10.89 \\
\hline No & 251 & 70.1 & 140 & 39.11 \\
\hline \multicolumn{5}{|l|}{ Complications } \\
\hline Yes & 190 & 53.1 & 107 & 29.89 \\
\hline No & 168 & 46.9 & 72 & 20.11 \\
\hline \multicolumn{5}{|l|}{ Risk of metabolic encephalopathy } \\
\hline$Y$ es & 50 & 14 & 36 & 10.06 \\
\hline No & 308 & 86 & 143 & 39.94 \\
\hline \multicolumn{5}{|l|}{ History of heart failure } \\
\hline Yes & 5 & 1.4 & 2 & 0.56 \\
\hline No & 353 & 98.6 & 177 & 49.44 \\
\hline \multicolumn{5}{|l|}{ Use of ventilators } \\
\hline$Y$ es & 14 & 3.9 & 13 & 3.63 \\
\hline No & 344 & 96.1 & 166 & 46.37 \\
\hline
\end{tabular}

Table 2. Relationship between predictive factors of mortality and death of ischemic stroke patients

\begin{tabular}{|c|c|c|c|c|c|}
\hline Variable & Died (179) & Lire (179) & OR & $95 \% \mathrm{CI}$ & $p$ \\
\hline \multicolumn{6}{|l|}{ Gender } \\
\hline Male & 75 & 80 & Ref & & 0.594 \\
\hline Female & 104 & 99 & 0.89 & $0.58-1.35$ & \\
\hline \multicolumn{6}{|l|}{ Age } \\
\hline $40-50$ years & 10 & 30 & $\operatorname{Ref}$ & & \\
\hline $51-60$ years & 38 & 43 & 2.65 & $107-6.70$ & \\
\hline $61-70$ years & 57 & 59 & 2.90 & $122-7.02$ & \\
\hline$>70$ years & 74 & 47 & 4.72 & $1.99-11.46$ & \\
\hline \multicolumn{6}{|l|}{ Level of consciousness } \\
\hline Compos mentis & 78 & 120 & $\operatorname{Ref}$ & & \\
\hline Somnolence & 63 & 44 & 2.20 & $133-3.66$ & \\
\hline Stupor & 35 & 15 & 3.59 & $1.76-7.41$ & \\
\hline Coma & 3 & 0 & 6.13 & $0.63-146.63$ & \\
\hline \multicolumn{6}{|l|}{ Onset to admission time } \\
\hline$<3$ hous & 17 & 19 & Ref & & \\
\hline $3-6$ hours & 35 & 37 & 1.06 & $0.44-2.54$ & \\
\hline $6-12$ hours & 25 & 26 & 1.07 & $0.42-2.76$ & \\
\hline 12-24 hours & 18 & 23 & 0.87 & $032-2.37$ & \\
\hline$>24$ hours & 84 & 74 & 1.27 & $058-2.78$ & \\
\hline \multicolumn{6}{|l|}{ Smoking } \\
\hline No & 175 & 169 & Ref & & 0.102 \\
\hline $\mathrm{Y}$ es & 4 & 10 & 0.38 & $0.11-1.25$ & \\
\hline \multicolumn{6}{|l|}{ Muscle strengh } \\
\hline $\begin{array}{l}\text { Active movem ent against full } \\
\text { resistance }\end{array}$ & 25 & 41 & $\operatorname{Ref}$ & & \\
\hline $\begin{array}{l}\text { Active m ovem ent against } \\
\text { some resistance }\end{array}$ & 18 & 35 & 0.84 & $037-1.92$ & \\
\hline $\begin{array}{l}\text { Active movem ent against } \\
\text { gravity }\end{array}$ & 18 & 22 & 1.34 & $056-3.22$ & \\
\hline $\begin{array}{l}\text { Active m ovem ent with } \\
\text { elimination of gravity }\end{array}$ & 17 & 12 & 2.32 & $087-6.24$ & \\
\hline F ew visible contractions & 55 & 44 & 2.05 & $1.03-4.08$ & \\
\hline No visibl e contractions & 3 & 7 & 0.70 & $0.13-3.44$ & \\
\hline
\end{tabular}


Table 2. Cont.

\begin{tabular}{|c|c|c|c|c|c|}
\hline Variable & Died (179) & Live (179) & OR & $95 \% \mathrm{CI}$ & $\mathbf{p}$ \\
\hline Undetermined & 43 & 18 & 3.92 & $1.75-8.84$ & \\
\hline \multicolumn{6}{|l|}{ Side of weakness } \\
\hline N either & 33 & 44 & Ref & & \\
\hline Left & 57 & 62 & 1.23 & $0.66-2.28$ & \\
\hline Right & 59 & 60 & 1.31 & $0.71-2.43$ & \\
\hline Bdh & 8 & 7 & 1.52 & 0.445 .28 & \\
\hline Undetermined & 22 & 6 & 4.89 & $163-15.29$ & \\
\hline \multicolumn{6}{|l|}{ Systolic BP (mm Hg) } \\
\hline$\leq 129$ & 41 & 23 & Ref & & \\
\hline $130-139$ & 21 & 27 & 0.44 & $0.19-1.00$ & \\
\hline$\geq 140$ & 117 & 129 & 0.51 & $028-0.93$ & \\
\hline \multicolumn{6}{|l|}{ Diastolic $\mathrm{BP}(\mathrm{mmHg})$} \\
\hline$\leq 84$ & 76 & 51 & Ref & & \\
\hline 8589 & 0 & 0 & & & \\
\hline$\geq 90$ & 103 & 128 & 0.54 & 0.340 .83 & \\
\hline \multicolumn{6}{|c|}{ Leuk ocyte count $\left(\times 10^{3} / \mathrm{mm}^{3}\right)$} \\
\hline$\leq 11$ & 91 & 111 & $\operatorname{Ref}$ & & 0.033 \\
\hline$>11$ & 88 & 68 & 1.57 & $1.03-2.40$ & \\
\hline \multicolumn{6}{|c|}{ Random tood glucose $(\mathrm{g} / \mathrm{dL})$} \\
\hline$<200$ & 120 & 146 & $\operatorname{Ref}$ & & 0.002 \\
\hline$\geq 200$ & 59 & 33 & 2.17 & $1.33-3.55$ & \\
\hline \multicolumn{6}{|l|}{ Atrial fibrill ation } \\
\hline No & 171 & 171 & $\operatorname{Ref}$ & & 1.000 \\
\hline$Y$ es & 8 & 8 & 1.00 & $0.36-2.72$ & \\
\hline \multicolumn{6}{|c|}{ History of diabetes m ellitus } \\
\hline No & 166 & 174 & $\operatorname{Ref}$ & & 0.053 \\
\hline$Y$ es & 13 & 5 & 2.72 & $0.95-7.81$ & \\
\hline \multicolumn{6}{|l|}{ History of hypertension } \\
\hline No & 89 & 80 & $\operatorname{Ref}$ & & 0.341 \\
\hline$Y$ es & 90 & 99 & 0.81 & $0.53-1.23$ & \\
\hline \multicolumn{6}{|l|}{ History of dyslipidemia } \\
\hline No & 140 & 111 & Ref & & 0.001 \\
\hline$Y$ es & 39 & 68 & 0.45 & $0.28-0.72$ & \\
\hline \multicolumn{6}{|l|}{ Complications } \\
\hline No & 72 & 96 & $\operatorname{Ref}$ & & 0.011 \\
\hline$Y$ es & 107 & 83 & 1.71 & $1.13-2.61$ & \\
\hline \multicolumn{6}{|c|}{ Risk of metabolic encephalopathy } \\
\hline No & 143 & 165 & $\operatorname{Ref}$ & & 0.001 \\
\hline$Y$ es & 36 & 14 & 2.96 & $1.53-5.72$ & \\
\hline \multicolumn{6}{|l|}{ History of heart failure } \\
\hline No & 177 & 176 & $\operatorname{Ref}$ & & 0.625 \\
\hline$Y$ es & 2 & 3 & 0.66 & $0.10-4.01$ & \\
\hline \multicolumn{6}{|l|}{ Use of ventilators } \\
\hline No & 166 & 178 & $\operatorname{Ref}$ & & 0.001 \\
\hline$Y$ es & 13 & 1 & 13.94 & $1.80-107.73$ & \\
\hline
\end{tabular}

Table 3. Multivariate analysis with logistic regression of mortality risk factors

\begin{tabular}{lccc}
\hline \multicolumn{1}{c}{ Variable } & OR & $\mathbf{9 5 \%}$ C I & p \\
\hline Age (>50 years) & 4.539 & $1974-10.439$ & $<0.001$ \\
Highr andom blood glucose & 2.692 & $1.580-4.588$ & $<0.001$ \\
Non-dyslipi demia & 2.313 & $1.395-3.833$ & 0.001 \\
Complications & 1.609 & $1.019-2.540$ & 0.041 \\
Risk of metabolic encephal cpathy & 2.499 & $1.244-5.021$ & 0.010 \\
Use of ventilators & 17.278 & $2.015-148.195$ & 0.009 \\
\hline
\end{tabular}


The data in Table 3 on multivariate analysis with logistic regression list the variables that have a significant relationship with mortality in ischemic stroke patients, i.e. age, random blood glucose concentration, non-dyslipidemia, complications, risk of metabolic encephalopathy and use of ventilators $(\mathrm{p}<0.05)$.

The results of the analysis show that there are variables that are associated with mortality in ischemic stroke patients, i.e. age (OR: 4.539, 95\% CI: 1.974-10.439, p<0.001), random blood glucose (OR: 2.692, 95\% CI: 1.580-4.588, $\mathrm{p}<0.001$ ), non-dyslipidemia (OR: 2.313, 95\% CI: 1.395-3.833, p<0.001), complications (OR: $1.609,95 \%$ CI: $1.019-2.540, \mathrm{p}=0.041)$, risk of metabolic encephalopathy (OR: $2.499,95 \% \mathrm{CI}$ : 1.244-5.021, $\mathrm{p}=0.010$ ) and use of ventilators (OR: 17.278, 95\% CI: 2.015-148.195, $\mathrm{p}=0.009$ ). The discrimination value of the scoring model in this study was 0.692 ; (95\% CI $0.638-0.746$; $\mathrm{p}<0.001)$. The larger the AUC the better the overall accuracy of the test. In this study the AUC value lies between 0.50 and 0.75 , thus it can be said that the overall accuracy of the test is fair. The value of $p<0.001$ shows that the test is proven to be able to predict the mortality.

\section{DISCUSSION}

Based on the results of the study it is known that with advancing age, the mortality risk in stroke patients is also increased. Patients who are over 50 years old have a higher mortality risk as compared with patients who are less than 50 years old. According to the study by Fonarow et al. ${ }^{(11)}$ elderly patients have a higher prevalence of disorders such as atrial fibrillation, hypertension, coronary heart disease, a history of stroke and a smoking habit. Elderly patients commonly die in hospital instead of at home, for each 10-year increase in age.

Patients with high random blood glucose have a 2.6 times higher mortality risk compared with patients with normal random blood glucose. From a study on focal experimental ischemia by Piironen et al. ${ }^{(12)}$ it is known that hyperglycemia can increase the size of the infarct and decrease the therapeutic window of recanalization.

Patients without dyslipidemia have a 2.3 times higher mortality risk than do patients with dyslipidemia. That dyslipidemia is a factor that reduces the mortality risk in patients with ischemic stroke is still a controversial issue. According to Sohail et al. ${ }^{(13)}$ high concentrations of triglycerides and low-density lipoprotein (LDL) and low concentration of high-density lipoprotein (HDL) are associated with high scores on the modified Rankin Scale (mRS), with severe stroke and poor clinical outcomes. The results of the aforementioned study contradict those of the study by Muhammad et al. ${ }^{(14)}$ who showed that patients with high total cholesterol concentrations have good clinical outcomes, since the cholesterol functions as a buffer for neutralizing free radicals and preventing injury to neural tissues.

Patients with complications such as gastrointestinal bleeding, urinary tract infections, and dysphagia have a 1.6 times higher mortality risk compared with patients without complications. According to a study conducted by Ogata et al. ${ }^{(15)}$ gastrointestinal bleeding after the onset of stroke can cause a decrease in hemoglobin concentration, neurological damage, poor functional results and death. Another complication, i.e. urinary tract infection occurring during hospitalization of the stroke patients, such as put forward by Poisson et al. ${ }^{(16)}$ have a characteristic impact, i.e. increased duration of hospital stay, increased health care costs, exposure to intravenous antibiotics, the risk of bacteriemia, decreased neurological status, poor clinical outcomes, and increased mortality risk.

Patients with a risk of metabolic encephalopathy have a 2.4 times higher mortality risk compared with patients without a risk of metabolic encephalopathy. The study conducted by Rodrigues et al. ${ }^{(17)}$ about 'Hyponatremia in the prognosis of acute ischemic stroke' showed that hyponatremia is associated with mortality in patients with acute ischemic stroke. According 
to Zhang et al. ${ }^{(18)}$ the serum urea concentration of patients with acute ischemic stroke who are treated with intravenous tissue plasminogen activator ( $\mathrm{r}$-tPA) is independently associated with poor clinical results and death of the patients.

Patients who use ventilators during hospitalization have a 17.2 times higher mortality risk compared with patients who do not use ventilators. The study by Mayer et al. ${ }^{(19)}$ states that two-thirds of stroke patients who use mechanical ventilators die during hospitalization and the majority of patients who survive experience severe disabilities. Patients who experience coma or worsening of their clinical condition after intubation have an extremely low chance of survival.

The discrimination value of the scoring model in this study is 0.692 (95\% CI 0.638-0.746; $\mathrm{p}<0.001)$. The larger the AUC the better the overall accuracy of the test. In this study the AUC value lies between 0.50 and 0.75 , thus it may be said that the overall test accuracy is fair. This value shows that this model is proven to be able to predict mortality.

One study demonstrates the importance of staffing levels and having a reasonable catchment population/stroke service as key factors associated with a better mortality outcome in stroke, which is one of the biggest killers globally. ${ }^{(20)}$ Variable staff composition in hospitals was not investigated in our study and is one of the limitations of the study.

Another limitation of the present study is the nested case control design using secondary data, i.e. from the stroke registry and medical records of ischemic stroke patients at Bethesda Hospital, Yogyakarta. A limitation that is difficult to avoid is that the investigators were unable to control the condition and quality of the measurements performed by other persons in the past, because of the use of secondary data.

It is hoped that clinicians may be able to perform a good evaluation of the condition of the patients and appropriately determine the prognosis of these patients so that the patients' condition can be reported more accurately to their families.
If in the future similar studies will be conducted, it is suggested that they use a different study method, e.g. a prospective cohort study using primary data so that the patients may be directly followed up.

\section{CONCLUSIONS}

Age, high random blood glucose concentration, complications, risk of metabolic encephalopathy, and use of ventilators are associated with mortality in ischemic stroke patients. The management of ischemic stroke should focus on the prevention of complications, thus decreasing mortality risk.

\section{CONFLICT OF INTEREST}

The authors declare that there is no conflict of interest with the parties associated in this study.

\section{ACKNOWLEDGEMENTS}

The authors thank the Duta Wacana Christian University for the funding of this study and the staff of Bethesda Hospital, Yogyakarta, for the use of their facilities during the study and for their kind assistance.

\section{CONTRIBUTION}

RTP, TB and EA contributed to prepare the manuscript. RTP contributed to design the research, and responsible for the final content RTP, TB and EA contributed to collected and analyzed the data; Rizaldy Pinzon contributed to wrote the manuscript, and all authors read and approved the final manuscript.

\section{REFERENCES}

1. Sacco RL, Kasner SE, Broderick JP, et al. On behalf of the American Heart Association Stroke Council, Council on Cardiovascular Surgery and Anesthesia, Council on Cardiovascular Radiology and Intervention, Council on Cardiovascular and Stroke Nursing, Council on 
Epidemiology and Prevention, Council on Peripheral Vascular Disease, and Council on Nutrition, Physical Activity and Metabolism . An updated definition of stroke for the $21^{\text {st }}$ century: a statement for healthcare professionals from the American Heart Association/American Stroke Association. Stroke 2013;44:2064-89. doi: 10.1161/STR.0b013e318296aeca.

2. Kementerian Kesehatan RI. Riset kesehatan dasar (Riskesdas 2013). Jakarta; Badan Penelitian dan Pengembangan Kesehatan, Kementerian Kesehatan RI; 2013.

3. Pinzon R. Profil stroke: gambaran tentang pola demografi, faktor resiko, gejala klinik, dan luaran klinis pasien stroke. Yogyakarta: Betha Grafika; 2014.

4. Carter AM, Catto AJ, Mansfield MW, et al. Predictive variables for mortality after acute ischemic stroke. Stroke 2007;38:1873-80. doi: 10.1161/strokeaha.106.474569.

5. Mogensen UB, Olsen TS, Andersen KK, et al. Cause-specific mortality after stroke: relation to age, sex, stroke severity, and risk factors in a 10-year follow-up study. J Stroke Cerebrovasc Dis 2013;22:e59-65.

6. Ivanov A, Ambreen M, Korniyenko A. Permissive hypertension in acute ischemic stroke: is it a myth or reality? J Am Coll Cardiol 2015;Suppl.10S:A1344.

7. Aksoy D, Inanir A, Ayan M, Cevik B, et al. Predictor of mortality and morbidity in acute ischemic stroke. Arch Neuropsychiatry 2013;50: 40-4.

8. Çomoðlu SS, Çilliler AE, Güven H. Erythrocyte sedimentation rate: can be a prognostic marker in acute ischemic stroke. Turkish J Cerebrovasc Dis 2013;19:18-22. doi: 10.5505/tbdhd.2013. 32042.

9. Kasner SE. Clinical interpretation and use of stroke scales.Lancet Neurol 2006;5:603-12.

10. Fan J, Upadhye S, Worster A. Understanding receiver operating characteristic (ROC) curves. Can J Emerg Med 2006;8:19-20.
11. Fonarow GC, Reeves MJ, Zhao X, et al. Agerelated differences in characteristics, performance measures, treatment trends, and outcomes in patients with ischemic stroke. Circulation 2010;121:879-91.

12. Piironen K, Putaala J, Rosso C, et al. Glucose and acute stroke. Stroke 2012;43:898-902.

13. Sohail, A, Khatri IA, Mehboob N. Effect of dyslipidemia on severity and outcome of stroke using mRS scores in Northern Pakistani population. RMJ 2013:384;345-50;

14. Muhammad D, Javed M, Sheikh GA. Acute ischemic stroke; correlation between higher total cholesterol level and high Barthel index score in patients. Professional Med J 2015;22:276-80.

15. Ogata T, Kamouchi M, Matsuo R, et al. Gastrointestinal bleeding in acute ischemic stroke: recent trends from the Fukuoka Stroke Registry. Cerebrovasc Dis Extra 2014;4:156-64.

16. Poisson SN, Johnston SC, Josephson SA. Urinary tract infections complicating stroke: mechanisms, consequences, and possible solutions. Stroke 2010;414:e180-4.

17. Rodrigues B, Staff I, Fortunato G, et al. Hyponatremia in the prognosis of acute ischemic stroke. Stroke Cerebrovasc Dis 2014;23:850-4. doi: 10.1016/j.jstrokecerebrovasdis.2013.07.011.

18. Zhang Y, Churilov L, Meretoja A, et al. Elevated urea level is associated with poor clinical outcome and increased mortality post intravenous tissue plasminogen activator in stroke patients. J Neurol Sci 2013;332:110-5. doi: 10.1016/j.jns.2013.06.030.

19. Mayer SA, Copeland D, Bernardini GL, et al. Cost and outcome of mechanical ventilation for life-threatening stroke. Stroke 2000;31:2346-53.

20. Myint PK, Bachmann MO, Loke YK, et al. Important factors in predicting mortality outcome from stroke: findings from the Anglia Stroke Clinical Network Evaluation Study. Age Ageing 2017;46:83-90. doi: 10.1093/ageing/ afw 175 . 